\title{
A palavra
}

O sucesso da Revista Dental Press de Ortodontia foi construído sobre um pilar que, por sua vez, pode ser denominado por uma única palavra. A caneta de editor da Revista, que honradamente passo a empunhar neste número, a escreve há mais de dez anos - repetidamente - e não creio que a tinta irá esgotar-se, pois seu pigmento é encontrado em cada artigo publicado pelos pesquisadores e clínicos brasileiros, que se postam entre os melhores do mundo. E o pigmento tem se espalhado.

A publicação nacional cresceu em número e excelência, e o gráfico de seu crescimento mostra sinais de vigor. Nesse acelerado movimento em espiral, a Revista teve importante participação. Meus antecessores, Dr. Laurindo Zanco Furquim e Dr. Adilson Luiz Ramos, - que não substituo, mas sucedo - contribuíram para o aprimoramento da qualidade da produção científica ortodôntica brasileira, pelas zelosas correções e sugestões aos autores, das quais participaram nossos conselheiros e comitê editorial.

Há alguns anos, contaram-me meus predecessores, teses eram submetidas por inteiro para serem publicadas como artigos, e problemas metodológicos eram muito mais freqüientes. Mas esse cenário mudou.

Certos meses, a Revista chega a receber mais de 70 submissões de novos manuscritos. Vários deles são submetidos com excelente qualidade e se transformam em ótimos artigos, que seriam publicados em qualquer jornal internacional de Ortodontia. Mas então, o que leva os autores a submeterem seu árduo trabalho para publicação nesta Revista?

O fato de ela ter Qualis A e ser incluída na coleção SciELO poderia ser a explicação, mas não é. A Revista ter grande visibilidade, fazendo com que artigos aqui publicados, muitas vezes, sejam mais lidos - no Brasil - do que se estivessem em periódicos estrangeiros, também poderia ser, mas não é. A real razão dessa escolha é que a Revista foi erguida sobre o pilar da palavra credibilidade, e isso foi fruto do labor de toda uma classe. A credibilidade existe porque nasceu da visão que a Ortodontia brasileira não é fragmentada em grupos, ela é única; que a isenção editorial é uma premissa inquebrantável, não existindo favorecimentos; que o objetivo de nosso trabalho é, e sempre será, contribuir para a construção de um Brasil melhor.

Várias são as sensações que as palavras despertam. Uma delas, o sabor, está contida na seção $O$ que há de novo na Odontologia, que trata de um tipo raro de sinestesia. Outra, a frustração do desconhecimento, é minimizada pelo professor Consolaro no Insight Ortodôntico, que discorre sobre a falta de bases anatômicas e fisiopatológicas para explicar as alterações pulpares induzidas pela movimentação ortodôntica. E as palavras ainda podem trazer satisfação, como a sentida ao ler a entrevista do professor Ary dos Santos Pinto, que partilha suas experiências clínica e científica com os leitores.

Meios de comunicação leigos e científicos têm tratado do uso de células-tronco em diferentes condições. $\mathrm{O}$ estado da arte sobre seu uso na Odontologia pode ser apreciado em excelente artigo de revisão publicado por pesquisadores baianos.

$\mathrm{O}$ artigo que seleciono neste número, escrito por Shirasu e colaboradores, avalia parâmetros periodontais após o uso de dois tipos de contenção para dentes anteriores inferiores, e mostra que velhas práticas clínicas podem - ainda - ser as melhores.

Um "calcanhar de Aquiles" da Ortodontia é a reabsorção radicular. A possível existência de diferenças na quantidade de reabsorção entre duas técnicas ortodônticas rotineiramente empregadas é avaliada em uma pesquisa clínica. Os resultados são possivelmente interessantes para nossos consultórios.

Como se comportam os molares durante o processo de distalização com o uso de um aparelho Pendex unilateral? A resposta para esse questionamento e também para outros, relacionados ao atrito de braquetes, é encontrada em dois artigos de mecânica, impressos neste número da Revista.

Estatísticas estão presentes em quase todos os artigos científicos e esse assunto eu, sinesteticamente, acho delicioso. No presente número Mendes e Santos-Pinto revisam os erros estatísticos. $\mathrm{O}$ artigo merece ser lido na íntegra por todos os envolvidos em pesquisas. Tanto o trabalho é relevante que parte de seus conceitos está presente no artigo seguinte, que analisa a confiabilidade do uso de modelos digitais tridimensionais como exame auxiliar ao diagnóstico ortodôntico. O custo de armazenagem de modelos de gesso tem se tornado incrivelmente alto em algumas cidades do mundo, incluindo brasileiras. Assim, provavelmente, o emprego de eModels tornar-se-á freqüente em um futuro próximo.

Ortodontistas fazem contas para armazenar modelos, para comprar material de consumo, etc. Portanto vale a pena pausar os olhos sobre um artigo que aborda a relação comercial do ortodontista brasileiro com seu paciente.

Por fim, uma seqüência de quatro artigos se detém na morfologia facial de diferentes grupos de brasileiros. $\mathrm{O}$ primeiro testa a associação entre marcadores genéticos e indicadores morfológicos em uma amostra de fissurados labiopalatais. O segundo quantifica o crescimento da base craniana em diferentes tipos faciais. $\mathrm{O}$ terceiro determina, em amazonenses com oclusão normal, os valores cefalométricos de Wits. E o último analisa os padrões cefalométricos de Ricketts aplicados a indivíduos brasileiros com oclusão excelente.

A palavra escrita é uma singularidade humana. Dela extraímos sustento, prazer e sabedoria. Desejo que vocês, leitores, se deliciem com as palavras contidas neste número e delas façam muito bom proveito.

Boa leitura.

Jorge Faber

Editor 